\title{
APLIKASI METODE INTERPOLASI INVERSE DISTANCE WEIGHTING DALAM PENAKSIRAN SUMBERDAYA \\ LATERIT NIKEL \\ (Studi kasus di Blok R, Kabupaten Konawe-Sulawesi Tenggara)
}

\author{
Hendro Purnomo \\ Jurusan Teknik Pertambangan \\ Sekolah Tinggi Teknologi Nasional \\ Jalan Babarsari, Caturtunggal, Depok, Sleman, Yogyakarta \\ Email: hendro.purnomo.hpu@gmail.com
}

\begin{abstract}
Inverse Distance Weighting (IDW) is one of method for estimating values at unsampled locations based on the measurements at surrounding locations. This method is commonly used in mineral exploration practices because of simple and easily understood. Objective of this researched was to map the spatial distribution of the limonite ore and resource estimation of the nickel laterite with using IDW method to interpolate nickel grade and thickness of the mineralization zone. The study was based on the data as a result of sixty drill holes in the target generation stage. The power parameters include 1, 2, 3, 4 and 5 were used to compare the performance of inverse distance interpolator. To choose the power value for IDW was decided from Root Mean Square Error (RMSE) value that was obtained from cross validation procedure. Base on the smallest RMSE value was generated that IDW with power of 1 is the best procedure for estimating value of the Ni grade and limonite thickness. With assuming cut-off grade is $1.2 \% \mathrm{Ni}$ and density of the limonite ore is $1.6 \mathrm{ton} / \mathrm{m}^{3}$, resource of the limonite zone is 151.7 million ton of ore with average grade $1.45 \% \mathrm{Ni}$ or equal to \pm 2.2 million ton nickel. Result of the limonite ore mapping indicate that additional potential nickel resource still open to the south and northwest of the study area.
\end{abstract}

Keywords : IDW; interpolation; limonite; power; RMSE

\begin{abstract}
Abstrak
Inverse Distance Weighting (IDW) adalah salah satu metode interpolasi untuk menaksir suatu nilai pada lokasi yang tidak tersampel berdasarkan data disekitarnya. Metode ini sering digunakan dalam kegiatan eksplorasi karena dalam proses perhitungannya lebih sederhana dan mudah difahami. Tujuan penelitian ini dilakukan untuk memetakan sebaran bijih limonit secara lateral dan penaksiran sumberdaya nikel, dengan menggunakan metode interpolasi IDW dalam menaksir kadar Ni dan ketebalan zona mineralisasi. Penelitian ini dilakukan berdasarkan data hasil pengebeboran prospeksi sebanyak 60 titik bor. Parameter power yang digunakan dalam proses interpolasi adalah 1, 2, 3, 4 dan 5 sedangkan untuk pemilihan nilai power yang terbaik digunakan parameter Root Mean Square Error (RMSE) yang diperoleh dari prosedur cross validation. Berdasarkan nilai RMSE yang terkecil diperoleh bahwa metode IDW dengan nilai power 1 adalah yang terbaik untuk penaksiran kadar Ni dan ketebalan zona bijih limonit. Dengan asumsi nilai cut-off grade adalah $1,2 \% \mathrm{Ni}$ dan densitas limonit $1,6 \mathrm{ton} / \mathrm{m}^{3}$, hasil estimasi sumberdaya pada zona limonit adalah 151,7 juta ton bijih dengan kadar rata-rata $1,45 \% \mathrm{Ni}$ atau setara dengan $\pm 2,2$ juta ton logam nikel. Hasil pemetaan sebaran bijih menunjukkan bahwa potensi tambahan sumberdaya nikel masih terbuka kearah selatan dan barat laut daerah penelitian.
\end{abstract}

Kata Kunci : IDW; interpolasi; limonit; power; RMSE 


\section{Latar Belakang Masalah}

Beberapa metode interpolasi telah dikembangkan dalam perangkat lunak (sofiware), diantaranya adalah metode Inverse Distance Weighting (IDW) dan metode geostatistik kriging. Dalam dunia pertambangan dan eksplorasi metode interpolasi digunakan dalam penaksiran kadar suatu mineral berharga atau elemen-elemen lain pada lokasi-lokasi yang tidak tersampel atau tidak mempunyai data.

Pada kegiatan eksplorasi laterit nikel terutama pada tahapan prospeksi dan eksplorasi pendahuluan metode interpolasi IDW sering digunakan karena dalam proses perhitungannya metode ini lebih sederhana dan lebih mudah difahami, tidak seperti metode geostatistik kriging yang memerlukan tahapan pemodelan variogram sebelum proses perhitungan kriging itu sendiri. Selain itu metode kriging memerlukan data yang lebih banyak dibandingkan untuk metode IDW. Menurut Voltz dan Webster (1990) untuk mendapatkan model variogram yang stabil memerlukan 100 sampai 150 data, sedangkan metode IDW memerlukan minimal 14 data bila sebaran data cukup mewakili (Yasrebi dkk, 2009).

Beberapa penelitian mengenai hubungan antara parameter statistik dengan performa suatu metode interpolasi menunjukkan hasil yang tidak konsisten. Kravchenko dan Bullock (1999), Robinson dan Metternicht (2006) melaporkan bahwa hasil interpolasi pada data soil properties dengan nilai skewness tinggi $(>2,5)$ lebih akurat menggunakan metode IDW dengan power 4 dan data dengan nilai skewness rendah $(<1)$, IDW power 1 menghasilkan estimasi yang lebih baik. Sebaliknya Weber dan Englund (1994) melaporkan bahwa hasil interpolasi IDW power 1 pada data limbah terkontaminasi menghasilkan performa yang lebih baik untuk data dengan nilai skewness antara 4 sampai 6 , sedangkan IDW dengan nilai power besar menghasilkan performa yang baik untuk data yang mempunyai nilai skewness rendah. Gotway dkk (1996) menemukan bahwa hasil interpolasi IDW power 4 lebih akurat pada data dengan nilai Coefficient Variance $(\mathrm{CV})$ rendah $(<0,25)$ dan data dengan nilai $\mathrm{CV}$ tinggi $(>1)$ hasil interpolasi IDW power 1 akan lebih baik. Sementara Kravchenco dan Bullock (1999) melaporkan bahwa tidak ada korelasi yang signifikan antara nilai CV dengan nilai power yang digunakan pada metode IDW.

Secara umum profil endapan laterit nikel terdiri dari zona saprolit yang terletak di bagian bawah dan zona limonit di bagian atas. Zona saprolit umumnya mengandung kadar Ni lebih tinggi dan Fe rendah, sedangkan zona limonit mengandung kadar Ni relatif lebih rendah tetapi mempunyai kadar Fe lebih tinggi (Elias, 2002). Laterit nikel terbentuk sebagai produk residu dari pelapukan batuan ultra basa, yaitu suatu jenis batuan yang kaya dengan mineral olivin dengan kandungan Ni 0,2-0,4\% (Brand dkk, 1998).

Tujuan penelitian ini dilakukan untuk memetakan sebaran bijih limonit secara lateral yang mengandung Ni lebih besar dari nilai kadar batas (Cut-off Grade), dan penaksiran jumlah sumberdaya nikel pada zona limonit dengan menggunakan metode interpolasi IDW dalam penaksiran kadar Ni dan ketebalan zona mineralisasi, serta hubungan antara parameter statistik skewness dengan performa nilai power yang digunakan.

\subsection{Daerah Penelitian}

Daerah penelitian terletak di Blok R kabupaten Konawe, Sulawesi Tenggara, Indonesia (Gambar.1) dengan luas $\pm 12 \mathrm{~km}^{2}$. Total jumlah lubang bor 60 titik dengan ketebalan zona limonit mulai dari $1,3 \mathrm{~m}$ sampai $20 \mathrm{~m}$ (Gambar. 2). Untuk analisa geokimia kadar nikel (Ni), sampel diambil dari inti bor pada setiap lubang bor dengan interval $1 \mathrm{~m}$. 


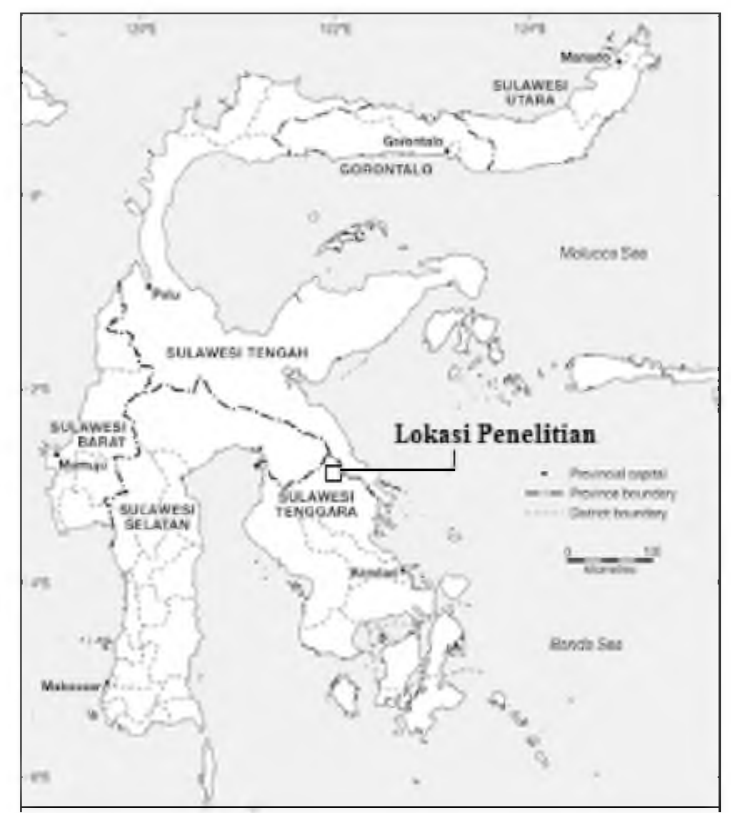

Gambar.1 : Lokasi daerah penelitian

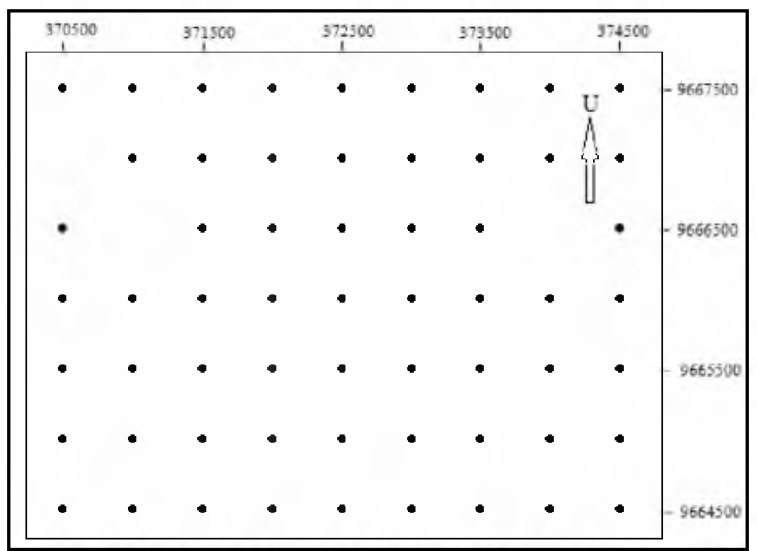

Gambar.2 : Sebaran lokasi titik bor di daerah penelitian

\subsection{Geologi Daerah Penelitian}

Secara geologi daerah penelitian terletak di bagian lengan tenggara pulau Sulawesi yang ditempati kelompok batuan ofiolit dengan struktur utama berarah barat laut - tenggara (Van Leuwen dkk, 2011), lihat Gambar 3. Menurut Simanjuntak dkk (1993) daerah penelitian dan sekitarnya ditempati kelompok batuan ofiolit yang terdiri dari harzburgit, lherzolit dan dunit. Ketiga jenis batuan ini diketahui sebagai sumber dari pembentukan endapan residu laterit nikel. 


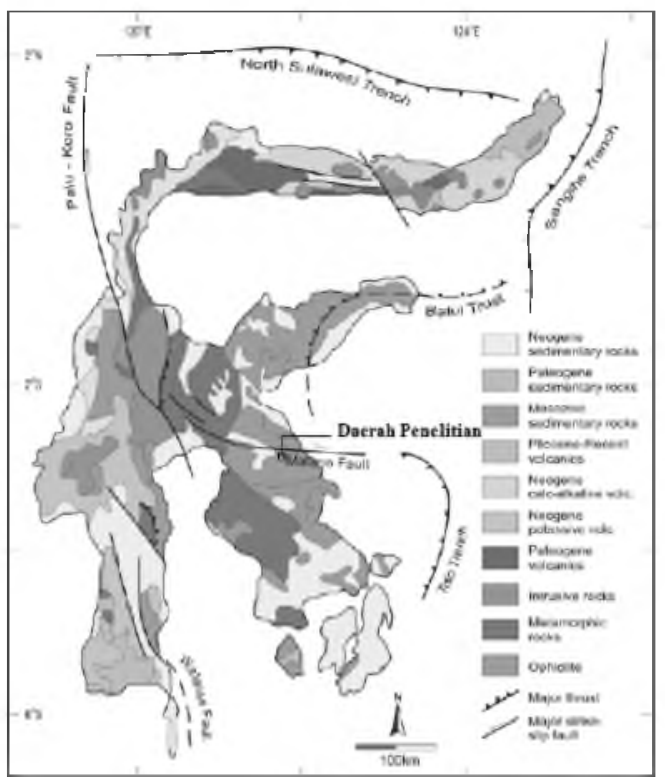

Gambar 3: Peta geologi regional P.Sulawesi (Van Leeuwen, dkk, 2011)

\section{Metodologi Penelitian}

Penelitian ini dilakukan berdasarkan data sekunder hasil dari pemboran pada tahap prospeksi. Pemboran dilakukan dengan pola grid berjarak $500 \mathrm{~m}$ antara satu titik lubang bor yang satu dengan titik lubang bor lainnya. Pengolahan data dilakukan dengan menggunakan aplikasi perangkat lunak (software) ArcGis v. 10.2 dan microsoft excel. Secara garis besar metode penelitian ini meliputi:

(a) Pengumpulan data dasar terdiri dari data koordinat X,Y (Easthing, Northing), kadar Ni dan kedalaman lubang bor pada zona limonit.

(b) Pengolahan basis data komposit pada setiap lubang bor yang dilakukan secara manual dengan menggunakan microsoft excel.

(c) Estimasi kadar $\mathrm{Ni}$ dan ketebalan lapisan limonit menggunakan metode interpolasi IDW power 1, 2, 3, 4 dan 5 .

(d) Melakukan validasi silang (cross validation) untuk membandingkan ketelitian hasil interpolasi pada masing-masing metode (IDW dengan nilai power 1, 2, 3, 4 dan 5).

(e) Evaluasi hasil interpolasi berdasarkan nilai Root Mean Square Error (RMSE), dimana hasil intepolasi dengan nilai RMSE terendah adalah yang terbaik.

(f) Pemodelan distribusi bijih limonit dan penaksiran sumberdaya nikel dilakukan berdasarkan hasil penaksiran kadar $\mathrm{Ni}$ dan ketebalan zona limonit dari metode interpolasi IDW yang terbaik.

(g) Tabulasi sumberdaya nikel.

Diagram alir metode penelitian dapat dilihat pada Gambar 4. 


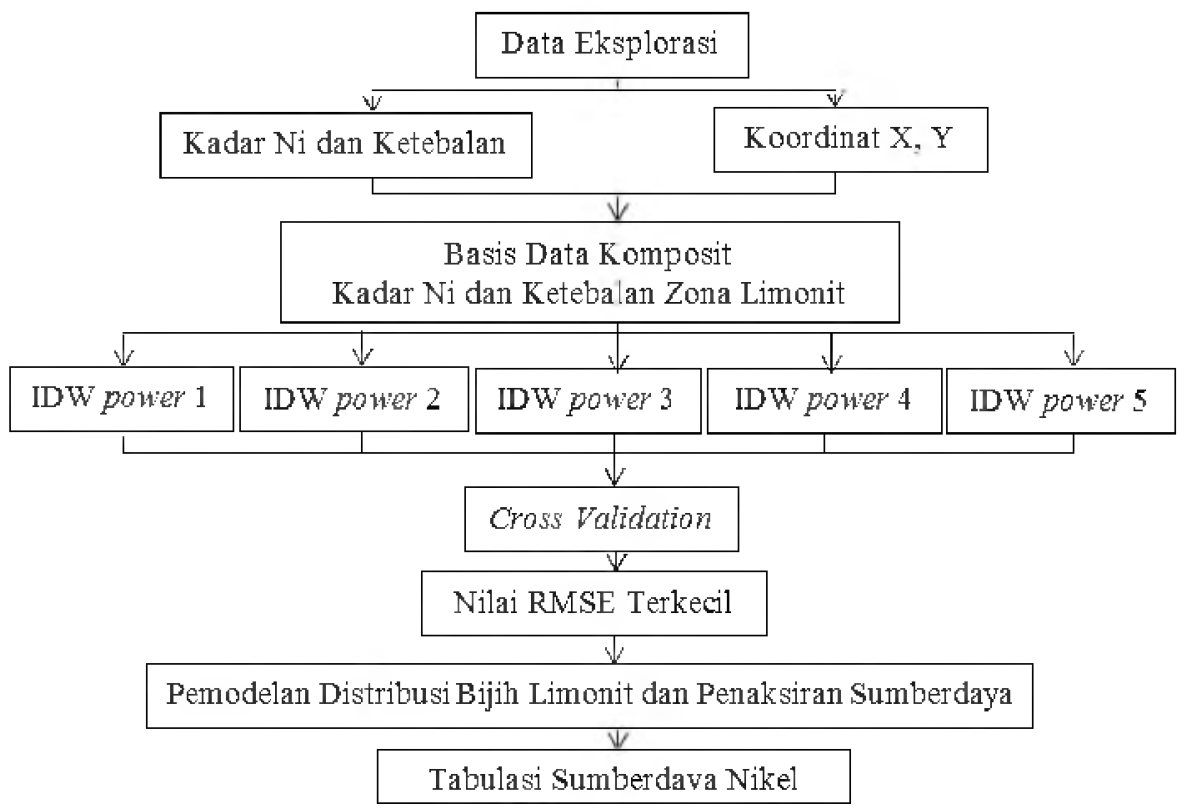

Gambar 4: Diagram alir metode penelitian

\subsection{Perhitungan Kadar Komposit}

Dalam perhitungan dengan cara dua dimensi diperlukan data kadar dalam bentuk nilai komposit (nilai rata-rata tertimbang). Data komposit dapat digunakan pada perangkat lunak tertentu, seperti Arc Gis, untuk selanjutnya ditampilkan dalam bentuk peta. Data yang digunakan dalam perangkat lunak aplikasi Arc Gis terdiri dari dua variabel yaitu: koordinat $\mathrm{X}$, Y dan kadar atau variabel yang lain seperti misalnya ketebalan. Persamaan untuk menghitung kadar komposit adalah sebagai berikut:

$$
\bar{g}=\frac{\sum_{i=1}^{n} t_{1} \cdot g_{1}}{\sum_{i=1}^{n} t_{i}}
$$

Keterangan :

$$
\begin{array}{ll}
\bar{g} & : \text { Nilai komposit } \\
_{1} & : \text { Ketebalan }(\mathrm{m}) \\
g_{i} & : \text { Kadar sampel pada interval-i }
\end{array}
$$

\subsection{Metode Inverse Distance Weighting (IDW)}

Metode IDW secara langsung mengimplementasikan asumsi bahwa sesuatu yang saling berdekatan akan lebih serupa dibandingkan dengan yang saling berjauhan. Untuk menaksir sebuah nilai di setiap lokasi yang tidak di ukur, IDW akan menggunakan nilai-nilai ukuran yang mengitari lokasi yang akan ditaksir tersebut. Pada metode IDW, diasumsikan bahwa tingkat korelasi dan kemiripan antara titik yang ditaksir dengan data penaksir adalah proporsional terhadap jarak. Bobot akan berubah secara linier, sebagai fungsi seper jarak, sesuai dengan jaraknya terhadap data penaksir (Almasi dkk., 2014). Bobot ini tidak dipengaruhi oleh posisi atau letak dari data penaksir dengan data penaksir yang lain.

Faktor penting yang dapat mempengaruhi hasil penaksiran antara lain adalah actor power dan radius disekitar (neighboring radius) atau jumlah data penaksir (Almasi dkk, 2014). Menurut Isaak dan Srivastava (1989) actor utama yang mempengaruhi keakuratan hasil penaksiran adalah nilai parameter power. Nilai parameter power yang umum digunakan adalah: 1, 2, 3, 4 dan 5 (Yasrebi dkk, 2009). 
Persamaan IDW yang digunakan dalam pembobotan adalah sebagai berikut (Isaak dan Srivastava, 1989):

$$
w_{i}=\frac{\frac{1}{d t^{p}}}{\sum_{i=1}^{n} \frac{1}{d t^{p}}}
$$

Untuk menghitung nilai titik yang ditaksir digunakan persamaan berikut :

$$
\hat{z}_{0}=\sum_{i=1}^{n} w_{i}, Z_{i}
$$

Keterangan :

$\dot{Z}_{0}$ : Nilai titik yang ditaksir.

$w_{\mathrm{i}}:$ Faktor bobot dari titik-i

$Z_{i}$ : Nilai dari titik penaksir-i

di: Jarak antara titik i dengan titik yang ditaksir

$p$ : Faktor eksponen (power) 1, 2, 3, 4, 5

\subsection{Evaluasi Metode Estimasi}

Untuk menilai tingkat ketelitian hasil interpolasi dari beberapa nilai power yang akan dipilih dilakukan pengujian dengan menggunakan cross validation (Isaak dan Srivastava, 1989). Cross validation merupakan statistik bivariate untuk menganalisis distribusi dua buah variabel yang berbeda tetapi terletak pada lokasi yang sama. Metode ini digunakan untuk mengetahui hubungan dan ketergantungan antar variabel.

Proses perhitungan cross validation dilakukan dengan cara pengambilan satu data sampel dari suatu set data secara bergantian untuk tidak diikutsertakan dalam proses interpolasi. Selanjutnya nilai sampel yang dipindahkan tadi dibandingkan dengan hasil penaksiran yang dihasilkan dari proses interpolasi pada titik tersebut dengan menggunakan seluruh sisa data yang tidak diambil. Selisih antara nilai data sampel yang diambil dengan nilai hasil penaksiran merupakan nilai kesalahan (error) dari penaksiran di lokasi tersebut. Untuk membandingkan hasil penaksiran dari setiap nilai power yang digunakan metode IDW, dilakukan evalusi dengan parameter statistik RMSE yang perhitungannya didasarkan pada nilai error pada setiap titik sample dari suatu set data.

Nilai RMSE dihitung dengan persamaan berikut (Olea, 1999) :

$$
R M S E=\sqrt{\frac{1}{n} \sum_{i=1}^{n}\left(\hat{Z}\left(x_{i}\right)-Z\left(x_{i}\right)\right)^{2}}
$$

Keterangan:

$$
\begin{array}{ll}
\hat{Z}\left(x_{i}\right) & : \text { Nilai estimasi } \\
Z\left(x_{i}\right) & : \text { Nilai pengukuran } \\
n & : \text { Jumlah prediksi }
\end{array}
$$

Hasil penaksiran dikatakan lebih akurat jika hasil interpolasi mempunyai nilai RMSE yang kecil.

\subsection{Penaksiran Sumberdaya}

Penaksiran sumberdaya dilakukan dengan menggunakan metode poligon atau disebut juga sebagai metode daerah pengaruh (area of influence). Pada metode ini semua faktor ditentukan untuk suatu titik tertentu pada endapan mineral, diekstensikan sejauh setengah jarak dari titik disekitarnya yang membentuk suatu daerah pengaruh (Gambar 5). 
Pada penelitian ini perhitungan sumberdaya menggunakan metode poligon-extended area, yaitu batas daerah pengaruh terluar dari poligon ini diekstensikan sampai sejauh setengah jarak antar titik-titik terdekat disekitarnya dari lokasi titik-titik bor terluar.

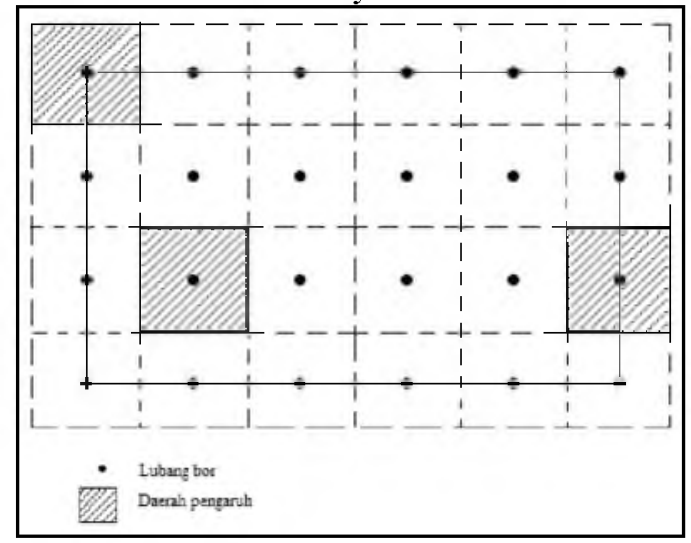

Gambar 5: Metode poligon-extended area

\section{Hasil dan Pembahasan}

\subsection{Basis Data Assay}

Pengolahan data pada penelitian ini dilakukan pada zona limonit. Data ketebalan dan hasil analisa geokimia Ni yang digunakan diperoleh dari 60 titik bor. Data mentah (raw data) kadar $\mathrm{Ni}$ dari setiap lubang bor kemudian diolah menjadi data komposit dengan menggunakan persamaan (1). Data komposit pada zona limonit di tabulasikan dalam spread sheet excel untuk kemudian digunakan sebagai basis data dalam perhitungan secara dua dimensi, dengan menggunakan aplikasi software Arc Giss V.10.2.

Hasil dari perhitungan data komposit diperoleh 27 sample dengan kadar $\mathrm{Ni}>1,2 \%$ dan 33 sampel dengan kadar $\mathrm{Ni} \leq 1,2 \%$. Tabel. 1 menunjukkan data komposit kadar $\mathrm{Ni}$ dan ketebalan zona limonit, sedangkan Gambar 6 menunjukkan distribusi sampel yang diklasifikasikan berdasarkan nilai Cut-off Grade 1,2\% Ni.

Tabel.1

Data komposit kadar Ni dan ketebalan pada zona limonit di daerah penelitian

\begin{tabular}{|c|c|c|c|c|c|c|c|c|}
\hline Lolasi & $\begin{array}{c}\mathbf{N i} \\
\mathbf{( \% )}\end{array}$ & $\begin{array}{c}\text { Ketebalan } \\
(\mathbf{m})\end{array}$ & Lokasi & $\begin{array}{c}\mathbf{N i} \\
\mathbf{( \% )}\end{array}$ & $\begin{array}{c}\text { Ketebalan } \\
(\mathbf{m})\end{array}$ & Lokasi & $\begin{array}{c}\mathbf{N i} \\
\mathbf{( \% )}\end{array}$ & $\begin{array}{c}\text { Ketebalan } \\
(\mathbf{m})\end{array}$ \\
\hline DH.1 & 1,12 & 9,3 & DH.21 & 1,12 & 10,5 & DH.41 & 1,16 & 11,0 \\
\hline DH.2 & 1,11 & 11,0 & DH.22 & 1,05 & 7,0 & DH.42 & 0,86 & 2,1 \\
\hline DH.3 & 1,11 & 9,7 & DH.23 & 1,86 & 12,0 & DH.43 & 0,93 & 4,0 \\
\hline DH.4 & 1,01 & 6,0 & DH.24 & 1,53 & 17,0 & DH.44 & 0,88 & 15,0 \\
\hline DH.5 & 1,4 & 16,0 & DH.25 & 1,01 & 3,0 & DH.45 & 1,01 & 20,0 \\
\hline DH.6 & 1,06 & 5,8 & DH.26 & 1,62 & 9,0 & DH.46 & 1,5 & 9,0 \\
\hline DH.7 & 1,38 & 13,0 & DH.27 & 1,35 & 15,0 & DH.47 & 0,91 & 7,5 \\
\hline DH.8 & 0,94 & 5,5 & DH.28 & 1,29 & 16,8 & DH.48 & 1,2 & 1,3 \\
\hline DH.9 & 1,43 & 13 & DH.29 & 1,43 & 15,0 & DH.49 & 1,52 & 15,0 \\
\hline DH.10 & 0,97 & 5,0 & DH.30 & 1,32 & 13,5 & DH.50 & 0,75 & 4,0 \\
\hline DH.11 & 1,28 & 12,0 & DH.31 & 1,02 & 7,6 & DH.51 & 0,72 & 4,0 \\
\hline DH.12 & 1,59 & 17,0 & DH.32 & 1,30 & 12,4 & DH.52 & 1,66 & 18,5 \\
\hline DH.13 & 1,40 & 14,0 & DH.33 & 1,23 & 10,0 & DH.53 & 0,95 & 8,5 \\
\hline DH.14 & 1,61 & 17,0 & DH.34 & 0,86 & 12,9 & DH.54 & 1,67 & 10,0 \\
\hline DH.15 & 1,1 & 7,0 & DH.35 & 1,31 & 12,7 & DH.55 & 1,27 & 17,6 \\
\hline DH.16 & 1,04 & 11,0 & DH.36 & 0,78 & 3,2 & DH.56 & 0,95 & 3,3 \\
\hline
\end{tabular}




\begin{tabular}{|c|c|c|c|c|c|c|c|c|}
\hline DH.17 & 1,73 & 12,5 & DH.37 & 1,2 & 10,0 & DH.57 & 1,01 & 4,6 \\
\hline DH.18 & 0,90 & 8,7 & DH.38 & 1,34 & 3,5 & DH.58 & 1,52 & 6,8 \\
\hline DH.19 & 0,88 & 18,0 & DH.39 & 1,09 & 17,0 & DH.59 & 0,92 & 1,3 \\
\hline DH.20 & 1,23 & 14,8 & DH.40 & 1,02 & 9,0 & DH.60 & 0,94 & 14,0 \\
\hline
\end{tabular}

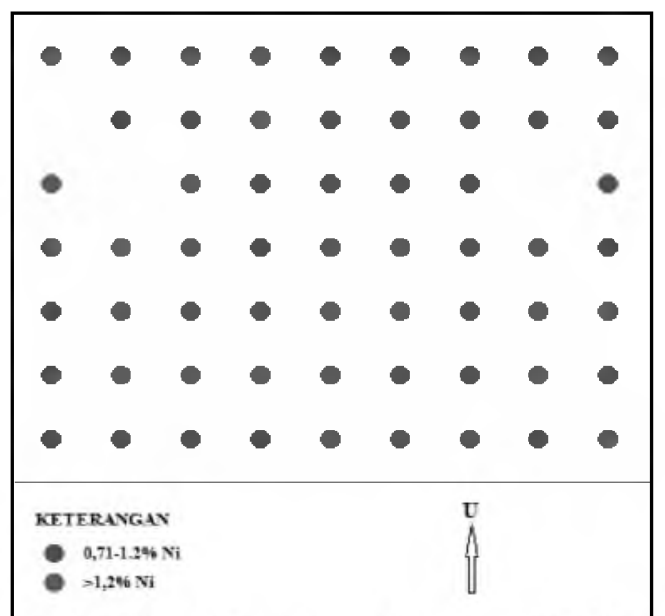

Gambar 6: Klasifikasi sampel menurut kadar nikel

\subsection{Analisis Statistik}

Analisis tatistic dilakukan pada kadar komposit Ni dan ketebalan zona limonit. Hasil analisis ini digunakan untuk mengetahui karakteristik data yang digunakan dalam penaksiran dengan menggunakan metode IDW. Tabel 2 menunjukkan hasil analisis tatistic kadar komposit Ni dan ketebalan. Di daerah penelitian.

Tabel 2

Hasil analisis tatistic kadar komposit Ni dan ketebalan

\begin{tabular}{|c|c|c|}
\hline Parameter & Ni (\%) & Ketebalan (m) \\
\hline Minimum & 0,72 & 1,3 \\
\hline Maksimum & 1,86 & 20 \\
\hline Rata-rata & 1,18 & 10,36 \\
\hline Std Deviasi & 0,27 & 4,94 \\
\hline Skewness & 0,46 & $-0,06$ \\
\hline Median & 1,12 & 10,25 \\
\hline Koefisien Variansi (CV) & 0,23 & 0,48 \\
\hline Jumlah data & 60 & 60 \\
\hline
\end{tabular}

\subsection{Penaksiran Kadar Ni dan Ketebalan}

Penaksiran kadar Ni dan ketebalan zona limonit pada lokasi-lokasi yang tidak tersampel dilakukan dengan metode interpolasi IDW. Metode ini merupakan teknik penaksiran yang menaksir nilai suatu titik berdasarkan pada nilai titik-titik contoh disekitarnya. Penaksiran dengan metode IDW dilakukan pada data komposit kadar Ni dan ketebalan zona limonit. Parameter yang digunakan dalam proses penaksiran adalah sebagai berikut:

- Radius pencarian data (search area) adalah $1250 \mathrm{~m}$

- Jumlah data maksimum yang digunakan sebanyak 10 data dan minimum 2 data.

- Parameter nilai power yang digunakan adalah 1,2,3,4 dan 5 . 
Peta hasil penaksiran metode IDW power 1 untuk kadar Ni dan ketebalan zona limonit disajikan pada Gambar 7, sedangkan nilai hasil penaksiran pada lokasi yang tidak tersampel (titik A, B danC) disajikan pada Tabel 3.

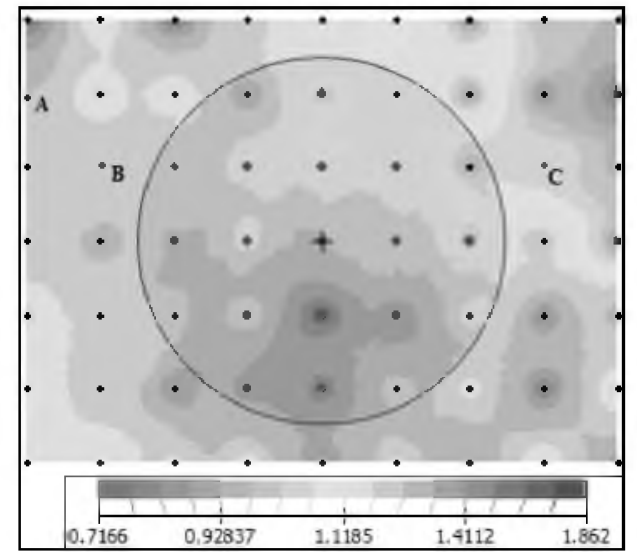

(a) IDW power 1 - kadar Ni

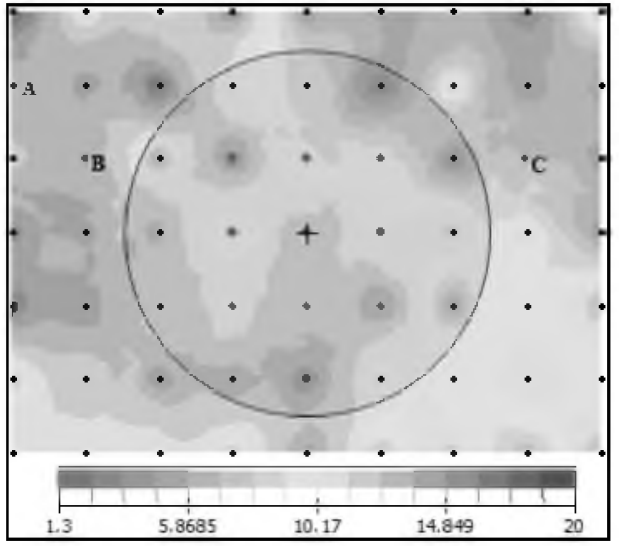

(b) IDW power 1 - ketebalan

Gambar 7: Peta hasil penaksiran IDW power 1 (a) kadar Ni dan (b) ketebalan

Tabel 3

Hasil penaksiran IDW power 1 untuk kadar Ni dan ketebalan

\begin{tabular}{|c|c|c|}
\hline Lokasi & Kadar Ni (\%) & Ketebalan (m) \\
\hline A & 1,25 & 13,3 \\
\hline B & 1,23 & 13 \\
\hline C & 1,05 & 6,9 \\
\hline
\end{tabular}

\subsection{Evaluasi Hasil Penaksiran}

Pemilihan nilai power terbaik yang digunakan pada metode IDW ditentukan berdasarkan nilai RMSE terkecil. Nilai RMSE ini diperoleh dari proses cross validation yang dilakukan pada masing-masing metode IDW dengan power 1 hingga power 5.

Tabel 4 menunjukkan nilai RMSE hasil penaksiran IDW dengan nilai power 1 sampai power 5. Dari tabel tersebut diperoleh bahwa nilai RMSE terkecil pada penaksiran kadar Ni dan ketebalan diperoleh dari metode IDW dengan power 1. Selanjutnya hasil penaksiran kadar Ni dan ketebalan dengan metode IDW power 1 tersebut digunakan dalam penaksiran sumberdaya dan distribusi bijih laterit nikel di daerah penelitian.

Tabel 4

Nilai RMSE hasil penaksiran IDW power 1-5

\begin{tabular}{|c|c|c|c|}
\hline Zona & Variabel & Metode & RMSE \\
\hline \multirow{4}{*}{} & \multirow{4}{*}{$\mathrm{Ni}$} & IDW 1 & 0,284986 \\
\cline { 3 - 4 } & & IDW 2 & 0,285686 \\
\cline { 3 - 4 } & & IDW 3 & 0,28794 \\
\cline { 3 - 4 } & & IDW 4 & 0,290365 \\
\cline { 3 - 4 } & & IDW 5 & 0,292277 \\
\cline { 3 - 4 } & \multirow{3}{*}{ Ketebalan } & IDW 1 & 4,976199 \\
\cline { 3 - 4 } & & IDW 2 & 5,208415 \\
\cline { 3 - 4 } & & IDW 3 & 5,428595 \\
\cline { 3 - 4 } & & IDW 4 & 5,612994 \\
\cline { 3 - 4 } & & IDW 5 & 5,756013 \\
\hline
\end{tabular}




\subsection{Sumberdaya}

Penaksiran sumberdaya nikel dalam penelitian ini menggunakan model dua dimensi dengan metode olygon-extended area, yaitu perhitungan endapan bijih per lubang bor yang mempunyai pengaruh sampai setengah jarak terhadap titik lain didekatnya, dengan asumsi setiap titik lubang bor mempunyai kadar dan ketebalan yang konstan dengan kadar dan ketebalan titik bor di dalam olygon tersebut.

Dalam perhitungan sumberdaya, data yang digunakan berdasarkan pada kadar estimasi $\mathrm{Ni}>$ cut off grade $(1.2 \% \mathrm{Ni})$ yang terletak di dalam batas perhitungan sumberdaya (outline) yang telah ditentukan. Sebaran hasil penaksiran kadar Ni dan batas perhitungan sumberdaya ditunjukkan pada Gambar 8. Jumlah tonase sumberdaya diperoleh dari jumlah seluruh tonase tiap olygon/blok yang diperoleh dari perkalian antara volume dengan densitas limonit. Sedangkan volume diperoleh dari perkalian antara luas blok (500X500) $\mathrm{m}^{2}$ dengan ketebalan lapisan limonit pada setiap lubang bor. Dalam penaksiran ini diasumsikan nilai densitas limonit adalah 1,6 ton $/ \mathrm{m}^{3}$ dan nilai cutoff grade $1,2 \% \mathrm{Ni}$.

Penaksiran sumberdaya dilakukan berdasarkan nilai kadar $\mathrm{Ni}$ dan ketebalan zona limonit hasil penaksiran dengan menggunakan metode IDW power 1. Hasil penaksiran sumberdaya nikel pada penelitian ini disajikan pada Tabel 5 .

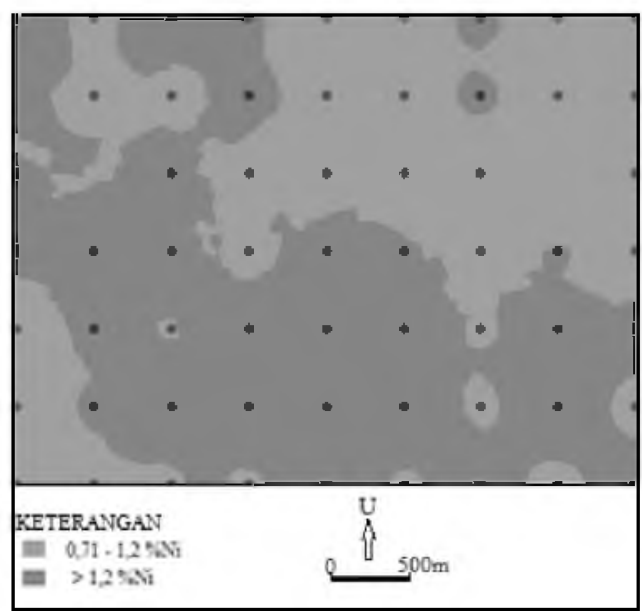

Gambar 8 : Peta sebaran kadar Ni dengan menggunakan metode IDW power 1.

Tabel 5

Hasil penaksiran sumberdaya nikel

\begin{tabular}{|c|c|c|}
\hline Bijih (Ton) & Kadar Rerata (\%Ni) & Jumlah Logam (Ton) \\
\hline 151.740 .000 & 1,45 & 2.201 .656 \\
\hline
\end{tabular}

\subsection{Diskusi}

Pemilihan nilai power yang terbaik berdasarkan nilai RMSE terkecil pada penaksiran kadar Ni dan ketebalan zona limonit, diperoleh bahwa hasil penaksiran metode interpolasi IDW dengan nilai power 1 (satu) adalah yang terbaik bila dibandingkan dengan IDW dengan nilai power 2, 3, 4 dan 5. Hal ini mungkin karena distribusi data dengan nilai skewness yang relatif rendah, yaitu 0,46 untuk kadar $\mathrm{Ni}$ dan $-0,06$ untuk ketebalan zona limonit. Hasil penaksiran ini konsisten dengan hasil penelitian pada data soil properties yang dilakukan oleh Kravchenko dan Bullock (1999) serta Robinson dan Metternicht (2006) bahwa data dengan nilai skewness $<1$ hasil penaksiran metode IDW dengan nilai power 1 adalah lebih baik bila dibandingkan dengan nilai power yang lain. Sedangkan nilai Koefisien Variansi (CV) menunjukkan tidak berkorelasi dengan nilai power yang digunakan. 
Hasil interpolasi metode IDW power 1 yang tersaji pada gambar 8 , menunjukkan bahwa distribusi kadar bijih limonit dengan warna merah adalah zona limonit dengan kadar $>$ $1,2 \% \mathrm{Ni}$, sedangkan daerah dengan warna biru dengan kadar $\leq 1,2 \% \mathrm{Ni}$. Jika diasumsikan bahwa nilai cut-off grade adalah $1,2 \% \mathrm{Ni}$, maka daerah dengan warna merah pada peta tersebut adalah merupakan daerah sebaran bijih limonit dengan kadar $>1,2 \% \mathrm{Ni}$. Peta tersebut menunjukkan bahwa sebaran bijih limonit terletak di bagian selatan dan menerus ke arah barat daya daerah penelitian. Dengan demikian tahap eksplorasi berikutnya atau pemboran eksplorasi yang lebih rinci dapat dilakukan di daerah anomali dengan kadar $\mathrm{Ni}>1,2 \%$. Untuk menambah potensi sumberdaya maka pemboran eksplorasi dapat di perluas kearah barat daya dan selatan sesuai dengan kecenderungan arah sebaran bijih limonit di daerah ini.

\section{Kesimpulan}

Hasil perbandingan nilai RMSE metode interpolasi IDW dengan nilai power 1, 2, 3, 4 dan 5 menunjukkan bahwa metode interpolasi IDW dengan nilai power 1 adalah yang terbaik untuk penaksiran kadar Ni dan ketebalan zona limonit dalam pemodelan sumberdaya dan sebaran bijih limonit secara lateral. Hal ini mungkin disebabkan karena sebaran data di daerah penelitian mempunyai nilai skewness yang relatif kecil.

Estimasi dengan menggunakan metode IDW dengan nilai power 1, menunjukkan bahwa sebaran bijih limonit dengan kadar $>1,2 \%$ Ni masih terbuka kearah selatan dan barat daya. Dengan asumsi nilai cut-off grade adalah 1,2\% Ni dan densitas limonit 1,6 ton $/ \mathrm{m}^{3}$, hasil estimasi sumberdaya pada zona limonit adalah 151,7 juta ton bijih dengan kadar rata-rata $1,45 \% \mathrm{Ni}$ atau setara dengan $\pm 2,2$ juta ton logam nikel.

Ekplorasi lebih rinci dengan jarak antar titik bor lebih rapat disarankan untuk dilakukan di daerah sebaran bijih limonit dengan kadar $>1,2 \% \mathrm{Ni}$ dan untuk menambah jumlah sumberdaya dapat dilakukan perluasan daerah pemboran prospeksi ke arah selatan dan barat daya daerah penelitian.

\section{Daftar Pustaka}

Almasi, A., Jalalia, A., Toomanian, N., 2014, Using OK and IDW Methods For Prediction The Spatial Variability Of A Horizon Depth and OM in Soils of Shahrekord, Iran. Journal of Environment and Earth Science, Vol.4, No 15.

Brand, N.W., Butt, C.R.M., Elias, M., 1998, Nickel Laterite: Classification Features. AGSO Journal of Australia Geology \& Geophysics, 17(4), 81-88.

Elias, M., 2002, Nickel Laterite Deposit - A Geological Overview, Resources and Exploration. Centre for Ore Deposit Research, University of Tasmania, Hobart, Special Publication 4, pp 205-220.

Gotway, C.A., Ferguson, R.B., Hergert, G.W., Peterson, T.A., 1996, Comparison of Kriging and Inverse Distance methods for mapping soil parameters. Am. J. Sci. 60, 1237-1247.

Isaaks, E.H. and R.M. Srivastava., 1989, Applied Geostatistics. Oxford University Press, New York.

Kravcencho, A.N., Bullock, D.G., 1999, A Comparative Study Of Interpolation Methods For Mapping Soil Properties. J. Agronomy 91, 393-400.

Olea, R.A., 1999, Geostatistics for Engineers and Earth Scientists. Kluwer Academic Publishers, London, UK.

Robinson, T.P., Metternicht, G., 2006, Testing the performance of spatial interpolation techniques for mapping soil properties. Computer and Electronics in Agriculture 50, pp 97-108.

Simanjuntak, T.O., Rusmana, E., Supandjono, J.B., 1993, Peta Geologi Lembar Bungku. Pusat Penelitian dan Pengembangan Geologi, Bandung. 
Sundari, W., 2012, Analisis Pada Eksplorasi Bijih Nikel Laterit Untuk Estimasi Cadangan dan Perancangan PIT Pada PT. Timah Eksplomin di Desa Baliara Kecamatan Kabaena Barat Kabupaten Bombana Provinsi Sulawesi Tenggara. Prosiding Seminar Nasional Aplikasi Sains \& Teknologi (SNAST) Periode III, Yogyakarta.

Van Leewen, T.M and Peters, P.E., 2011, Minerals Deposits of Sulawesi. Proceeding of The Sulawesi Minerals Resources, Seminar MGEI-IAGI.

Yasrebi, J., Saffari, M., Fathi, H., Karimian, N., Moazallahi, M and Gazni, R., 2009, Evaluation and Comparison Of Ordinary Kriging and Inverse Distance Weighting Method For Prediction Of Spatial Variability Of Some Soil Chemical Parameters. Research Journal of Biological Science 4(1): 93-102.

Voltz, M., Webster, R., 1990, A Comparison of Kriging, Cubic Splines and Classification for Predicting Soil Properties from Sample Information. J. Soil Sci. 41, 473-490.

Weber, D., Englund, E., 1994, Evaluation and Comparison Of Spatial Interpolators II. Math. Geol. 26, 589-603. 